COMPARATIVE MIGRATION STUDIES

www.comparativemigrationstudies.org

Published by: Amsterdam University Press

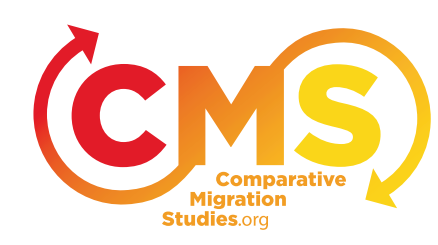

Introduction to the Special Issue

\title{
Lessons from Canada and Germany
}

Immigration and Integration Experiences Compared

Harald Bauder, Patti Tamara Lenard \& Christine Straehle

CMS 2 (1):1-7

DOI: $10.5117 / C M S 2014.1 . B A U D$

\section{Rationale and Objective}

There have been important similarities between Canada's and Germany's policies and approaches towards immigration and integration, ranging from practices of ethnic and racial exclusion in the first part of the last century to the subsequent development of both countries "into de-facto multicultural societies" (Triadafilopoulos, 2012: 2). However, because of significant differences in their historical contexts, as well as in the contemporary political and geographical circumstances that shape immigration and integration discourses and policies, considerable variations remain (Bauder, 2011). This special issue explores recent developments related to the immigration and integration experiences in both countries. Comparisons between Canada and Germany with respect to immigration and integration have become of increasing scholarly interest in recent years (e.g. Bauder, 2006b, 2008, 2011; Bendel and Kreienbrink, 2008; Reitz et al., 1999; Geißler, 2003; Schmidtke, 2010; Schultze, 1994; Triadafilopoulos, 2004, 2006, 2012; Winter, 2007; ZWH, $2009^{1}$ ). Apparently, comparisons of Canada and Germany have much to offer to migration research and policy making in that they "can de-center what is taken for granted" and thereby "challenge conventional wisdom" related to immigration and integration (Bloemraad, 2013: 29).

Recent political developments made it necessary to update and expand the existing comparative literature. Canada's immigration system is in the process of a significant overhaul. The Canadian government has lately 
altered the rules for admitting refugees; it has drastically expanded Canada's temporary foreign labour migration programs; it has transformed on an ongoing basis the role provinces can play in determining which migrants to admit; it has moved away from a focus on the "well-rounded" immigration towards a focus on migrants with skills that are in demand in the Canadian labour market; and it has begun to retreat from a commitment to accommodating diversity (e.g. Alboim and Cohl 2012). If these trends continue or the existing changes persist, the make-up of the Canadian labour force and the "face" of Canadian society will shift markedly in the next decade. Moreover, these changes come at a time when Canadian society is engaged in two important debates: a debate about Canada's role in the world, and a debate about Canada's social fabric and national identity. Both of these debates are strongly affected by and, in turn, influence Canada's immigration policy.

Germany has also implemented drastic changes in respect to its policies towards immigrants and their integration over the last two decades. These changes include revisions to citizenship legislation; the establishment of Germany's first immigration law; numerous policy initiatives aiming at the social inclusion of immigrants; and attempts to integrate non-Christian religious institutions more deeply in civil society. Nevertheless, it remains a common trope to describe Germany as an "ethnic" nation, which has historically been hostile to receiving and incorporating non-ethnic German migrants. While the "ethnic" understanding of nationhood continues to influence German immigration debates (Bauder, 2011, and this issue), Germany has made enormous progress with respect to accommodating the foreign and foreign-born population and integrating immigrants from around the world.

Yet, motivated by the perceived superiority of Canadian settlement and integration policies, German politicians routinely travel to Canada to learn about Canadian policies and methods of immigrant integration. For example, in 2011, Ryerson University hosted an the Roundtable on Immigration/Integration for the visit of Maria Böhmer, Minister of State to the Federal Chancellor and Federal Government of Germany and Commissioner for Migration, Refugees and Integration; a year later the Ryerson Centre for Immigration and Settlement (RCIS, www.ryerson.ca/rcis) organized a similar roundtable for the visit of the Parliamentary Committee on Integration of Ontario's German partner province, Baden-Württemberg. These events propagate the assumption that Germany must do the learning from immigrant-receiving nations like Canada.

This special issue challenges the analytical lens that knowledge on how to design effective immigration and integration policies should only transfer 
from Canada to Germany. Rather, this special issue considers what both Germany can learn from Canada as well as what Canada can learn from Germany's vast experience with immigrants, refugees and guest workers. This objective resonates with recent moves made by the Canadian government to transition from established patterns of admitting immigrants and refugees, towards more restrictive policies and practices that mirror the other countries' experiences with migration (Alboim and Cohl, 2012). For example, it can be argued that Canada's growing reliance on temporary foreign workers attempts to incorporate important lessons learned from Germany's experiences with its guest worker program of the 1950s-1970s, by ensuring that most temporary foreign workers cannot easily earn postnational citizenship, including the right to stay in Canada (Bauder, 2010).

The papers in this special issue will demonstrate that there is a great deal that can be learned from comparing the immigration and integration experiences in both countries. The value of this comparative approach lies in juxtaposing important differences and highlighting similarities between two countries that have been situated rather differently in terms of their history and geography, but which have also been part of interconnected global economic, political and migration systems. The learning experience for both countries involves several dimensions:

\section{National identity}

National identities have shaped attitudes, discourses and policies towards immigration, integration and citizenship. Germany has historically been described as fearful of migrants of non-German ethnic background, who threaten to dilute a German sense of nationhood. Yet, the country's recent trajectory has moved away from this historical conception. In contrast, Canada has long identified as being an immigration country and pioneer of multiculturalism. Yet, many Canadians have become fearful of "Others" representing immigrants and/or certain religious groups. In this special issue, Harald Bauder's paper explores the contradictions in immigration debates and policies in Canada and Germany, in an attempt to offer a fuller account of the relationship between national identity, ethnic belonging and immigration. This paper also establishes some of the underlying historical and discursive contexts that inform the subsequent contributions to this issue. 


\section{Citizenship}

Canada and Germany are frequently presented as ideal types of different models of national belonging. As a settler society, Canada is often depicted as a pluralistic-civic nation that embodies the prototype of multicultural citizenship. Conversely, Germany is often represented as an ethnic nation that follows the ius sanguinis principle (law of blood), passing citizenship on from one generation to the next, independent on where a person was born or migrated to. By examining both countries naturalization practices, Elke Winter contests these depictions of Canada and German as ideal types of citizenship. Rather, her research shows that both counties are facing similar challenges in respect to naturalization. Yet, the responses to these challenges continue to be shaped to a degree by national histories and identities.

\section{Labour}

The need for labour and employment is a driving force of migration to Canada and Germany. Germany's post-war guestworker program was among the largest of its kind and certainly one of the best known. The accumulation of postnational rights, however, enabled many of these "guest" workers to stay permanently in Germany. Today, too, the German economy benefits from an influx of labour from other European Union countries that possess social, economic and political rights as European citizens. Canada also today relies increasingly on both high- and low-skilled temporary labour migrants. Some of these migrants will have the opportunity to remain permanently in Canada, but many others will be required to leave, or they will become non-status migrants if they decided to stay (Lenard and Straehle, 2012). Analyzing recent policy developments, Holger Kolb demonstrates that both Canada and Germany indeed pursue hybrid approaches, although these approaches maintain distinct national characteristics.

\section{Governance}

Over many years, Germany has occupied a central and driving role in European attempts to harmonize immigration policy - a policy change that was adopted in the context of the Schengen agreement implemented in 1995 . Canada has not harmonized its migration policies with the United States 
and Mexico to the same degree. Oliver Schmidtke observes a scale-shift in the other direction: cities and sub-national regions are being increasingly important actors in the governance of migration and integration. Although this downloading of governance authority can be observed in both Canada and Germany, it is implemented in nationally particular ways.

\section{Refugees and asylum policy}

Germany has historically had one of the developed world's most generous asylum policies, but has recently integrated its refugee and asylum policies with the corresponding European policies and structures. As Canada faces the prospect of rising numbers of asylum applications and is embracing a global discourse of securitization, Germany's and other Europe's experiences have provided Canada with insight into revising its own policies towards refugees. Dagmar Soennecken shows in her paper that Canada may have once been a global innovator in respect to refugee policy and a respected leader of humanitarianism; today, however, Canada's refugee policies increasingly follow and adopt restrictive policy approaches that were pioneered in Europe. Again, while striking similarities exist between both Canadian and European policies, there are also important differences in the manner in which both ccountries incorporate national and regional contexts.

With their diverse scholarly and disciplinary backgrounds, the contributors to this special issue present multi- and interdisciplinary perspectives on the debate of Canadian and German immigration and integration experiences. Across these diverse perspectives, it becomes clear that Canada is no long the undisputed innovator of progressive immigration and refugee policies or settlement practices. Likewise, Germany can no longer be dismissed as an antiquated ethnic nation that is ill-equipped to handle the increasing global mobility of populations and that trails behind other nations in developing and implementing effective immigration and integration policies and practices. We hope that the papers in this special issue and the new information they present will prove useful not only to fellow researchers, but also to students, practitioners and policy makers in Canada and Germany, as well as in countries that share aspects of the immigration and integration experience with Canada and Germany. 


\section{Acknowledgements}

This special issue has its origin in the workshop "Germany's Immigration and Integration Experience - Lessons for Canada" held at the University of Ottawa on November 30 -December 1, 2012. This workshop was organized by Patti Tamara Lenard and Christine Straehle, and received financial support from the German Academic Exchange Service, University of Ottawa's Graduate School of Public and International Affairs, and the Centre for International Policy Studies. After the workshop, Harald Bauder continued developing the special issue based the workshop contributions. The publication of this special issue is supported by the Ryerson Centre for Immigration and Settlement (RCIS) and with a grant provided by the Office of the Dean of Arts, Ryerson University.

\section{Note}

1. In addition, Harald Bauder organized a workshop titled "Canada as an immigration model for Germany?" at the 2008 International Metropolis Conference held in Bonn; and recently, in October 2013, the workshop "Translating Welfare and Migration Policies in Canada and Germany," organized by Adrienne Chambon, Ernie Lightman, Wolfgang Schröer and Eberhard Raithelhuber, was held in Frankfurt am Main.

\section{References}

Alboim N and Cohl K (2012) Shaping the Future: Canada's Rapidly Changing Immigration Policies. Toronto: Maytree.http://maytree.com/wp-content/uploads/2012/10/shaping-the-future.pdf (last accessed 17 January 2013)

Bauder H (2006) Labor Movement: How Migration Regulates Labor Markets. New York: Oxford University Press.

Bauder H (2008) Kanada: Zuwanderungsmodell für Deutschland? Geographische Rundschau $60(2): 48-50$.

Bauder H (2010) Foreign Workers Present a Moral Dilemma: Canada has the Capacity, and Obligation to Integrate Guest Workers. Edmonton Journal, Nov. 15: A17.

Bauder H (2011) Immigration Dialectic: Imagining Community, Economy and Nation. Toronto: University of Toronto Press.

Bendel P and Kreienbrink A (eds.) (2008) Kanada und Deutschland: Migration und Integration im Vergleich. Nürnberg, De: Bundesamt für Migration und Flüchtlinge.

Bloemraad I (2013) The Promise and Pitfalls of Comparative Research Design in the Study of Migration. Migration Studies 1 (1): 27-46.

Geißler R (2003) Multikulturalismus in Kanada - Modell für Deutschland? Aus Politik und Zeitgeschichte, 26:19-25.

Lenard PT and Straehle C (eds.) (2012) Legislated Inequality: Temporary Labour Migration in Canada. Montreal-Kingston: McGill-Queen's University Press. 
Reitz J G, Frick J R, Calabrese T and Wagner G. (1999) The institutional framework of ethnic employment disadvantage: A comparison of Germany and Canada. Journal of Ethnic and Migration Studies, 25 (3): 397-443.

Schmidtke O (2010) Einwanderer als Ware: Wie die Marktlogik Migranten aussortiert. Blätter für deutsche und internationale Politik, 10: 51-57.

Schultze G (ed.) (1994) Einwanderungspolitik Kanada's und der USA: Beispiele für die Bundesrepublik Deutschland? Bonn, DE: Forschungsinstitut der Friedrich-Ebert-Stiftung, Apteilung. Arbeits- und Sozailforschung.

Triadafilopoulos $\mathrm{P}$ (2004) Building walls, bounding nations: Migration and exclusion in Canada and Germany, 1870-1939. Journal of Historical Sociology, 17 (4): 385-427.

Triadafilopoulos P (2006) A model for Europe? An appraisal of Canadian integration policies. In: Baringhorst S, Hunger U and Schönwälder K (eds.) Politische Steuerung von Integrationsprozessen:Intentionen und Wirkungen. Wiesbaden, DE: VS Verlag für Sozialwissenschaften, pp. 79-94.

Triadafilopoulos P (2012) Becoming Multicultural: Immigration and the Politics of Membership in Canada and Germany. Vancouver, BC: UBC Press.

Winter, Elke (2007) Bridging unequal relations, ethnic diversity, and the dream of unified nationhood: Multiculturalism in Canada. Zeitschrift für Kanada-Studien 1: 38-57

Zentralstelle für die Weiterbildung im Handwerk (ZWH) (2009) To Canada Migration nach Deutschland. Düsseldorf.

\section{About the authors}

Harald Bauder, Ryerson Centre for Immigration and Settlement, Ryerson University. Corresponding author.

E-mail: hbauder@ryerson.ca

Patti Tamara Lenard, Graduate School of Public and International Affairs, University of Ottawa.

Christine Straehle, Graduate School of Public and International Affairs, University of Ottawa.

2014 Bauder, Lenard \& Straehle / Amsterdam University Press.

This is an Open Access article distributed under the terms of the Creative Commons Attribution License (http:// creativecommons.org/licenses/by/2.0), which permits unrestricted use, distribution, and reproduction in any medium, provided the original work is properly cited. 